\title{
Prevention of respiratory infections at day care centers: recommendations and systematic review of the evidence
}

\author{
María Elina Serra, M.D. ${ }^{a}$
}

\begin{abstract}
Introduction. Attending a day care center is a risk factor for respiratory infections. The objective of this study is to review which nonspecific prevention measures are recommended for day care centers and the evidence of their usefulness in this setting.

Methods. Recommendations regarding nonspecific prevention at national level were searched using Google and the web sites of the Argentine Society of Pediatrics, the ministries of education and the ministries of health from different countries, both in English and Spanish. Recommendations regarding hand hygiene, clearance of secretions, cleaning the environment and elements, breastfeeding, and exclusion of symptomatic subjects were reviewed. A systematic search of the literature was conducted to find intervention studies at day care centers that evaluated the effectiveness of recommendations, published in Spanish and English. Results and the methodological quality of studies were analyzed.

Results. Seven guidelines were found. Hand hygiene and environment cleaning were the only recommendations described in all guidelines. The exclusion of symptomatic subjects is mentioned in all, but criteria are heterogeneous. Clearance of nasal secretions and promotion of breastfeeding are outlined only in a few of the guidelines.
\end{abstract}

Eight intervention studies on hand hygiene, cleaning of the environment, and clearance of secretions were found, whose results were heterogeneous and had major methodological limitations.

Conclusion. A timely and adequate hand hygiene and an appropriate cleaning of the environment have been uniformly recommended by different guidelines as non-specific prevention measures against respiratory infections. The evidence on the usefulness of these measures in this setting is limited.

Key words: day care centers, respiratory infections, infection prevention.

http:/ /dx.doi.org/10.5546/aap.2014.eng.323

E-mail address:

María Elina Serra,

M.D.:

meserra@fundasamin.

org.ar

Conflict of interest:

None.

Received: 11-21-2013

Accepted: 2-24-2014 percentage of respiratory infections are severe, in Argentina they account for the third cause of death in children younger than five years old and the second cause of death in infants younger than one year old. ${ }^{2}$

Infants younger than two years old are specially vulnerable to these diseases, including those who have no risk factors, because the anatomical and physiological characteristics of the respiratory tract at this age and the transient hypogammaglobulinemia of infancy make them prone to respiratory infections. Children who attend day care centers have a higher probability of acquiring an infectious disease given their increased exposure to pathogens, their frequent and close contact with other children, and the limitations of their own hygiene typical of their age. ${ }^{3}$

Spending several hours away from their mother could also have an effect on breastfeeding and make them even more vulnerable.

The complications of common events (such as recurrent otitis or lower respiratory infections), the widespread use of antibiotics for viral conditions (accompanied by the resulting increased microbial resistance), the implied costs of these infections, and their dissemination to the rest of the community account for a public health problem. ${ }^{3-5}$ To this date, there is no active immunization available against the most common etiology of these infections (syncytial respiratory virus). Moreover, there is no evidence of a useful, available treatment for bronchiolitis, the most common lower respiratory tract infection. ${ }^{6}$ 
Infectious disease prevention can be approached through specific measures (active or passive immunizations against a particular etiologic agent) or non-specific measures (health promotion measures, such as hand washing or the exclusion of sick subjects). Early education organizations, government agencies and societies of pediatrics from different countries have issued non-specific prevention guidelines aimed at reducing the dissemination of infections. These recommendations propose approaches based on different themes, but their feasibility, effectiveness and impact in the setting of day care centers should be assessed.

The objectives of this study were:

a. To establish which non-specific measures are commonly suggested in the guidelines or the official recommendations of different countries.

b. To review the available evidence regarding the usefulness of these measures to reduce the dissemination of respiratory infections at day care centers.

\section{METHODS}

\section{Search for recommendations}

In Google, we searched national standards published by government authorities or by societies of pediatrics, either in English or Spanish (English terms were: guidelines, statement, recommendations, day care, childcare and infection prevention; Spanish terms were: guias/ recomendaciones, guardería, jardin maternal, centro de cuidado infantil and prevención de infecciones). We then expanded the search by visiting the web sites of the society of pediatrics and the ministry of health and the ministry of education of Argentina, Chile, Uruguay, Paraguay, Mexico, Colombia, Peru, Cuba, Bolivia, Costa Rica, Dominican Republic, Ecuador, El Salvador, Guatemala, Honduras, Nicaragua, Panama, and Spain. Documents were selected if they included non-specific prevention measures. Documents were excluded if they described only specific prevention measures or if they had been published by provincial or regional entities (versus national agencies).

Recommended measures were analyzed in relation to the following thematic focuses: ${ }^{7-9}$

- Hand hygiene.

- Breastfeeding.

- Clearance of nasal secretions.

- Cleaning of the environment and commonly used elements.

- Exclusion of symptomatic subjects.

\section{Literature search for available evidence}

A qualitative systematic review was developed.

A literature search was conducted during November 2012 using Medline, Cochrane Library, Scielo, BVS and Google Scholar. For key terms, the following MeSH descriptors were used: Child Day Care Centers, respiratory tract infection, and prevention; and the following DeCS descriptors: jardines infantiles, prevención de enfermedades, infecciones del sistema respiratorio. Given the scarce number of studies in this field, no filters were applied regarding the type of study.

We also reviewed files corresponding to research studies presented at the congresses organized by the Argentine Society of Pediatrics from 2005 to $2012^{10}$ and those presented at the annual Pediatric Academy Societies meetings in 2011 and 2012..$^{11,12}$

Studies were selected if they assessed the effectiveness of measures related to our thematic focuses, published either in Spanish or in English. Studies developed at day care centers or childcare facilities, whose outcome measure considered the impact of the infection rate, respiratory symptoms or the severity of infections in children who attended these places were included. In this study, recommendations and studies regarding pharmacological interventions and immunization and/or chemoprophylaxis were excluded because they are specific prevention measures. In addition, studies on the level of knowledge or attitudes of parents or day care center staff and studies conducted at schools or day care centers attended only by children older than three years old were excluded.

The bibliographic references of each relevant (selected) study were reviewed in order to find additional studies.

Data were collected using a specificallydesigned template.

Study quality was assessed taking into account the recruitment bias, the baseline imbalance among participating individuals, clusters or centers, participant loss throughout the study, and a correct statistical analysis (considering inter-cluster variability, if applicable). Participant and study personnel blinding, sample size, assessment of whether or not the intervention was complied with, the presence of conflicts of interest, other potential sources of bias, and clear, complete and nonselective result reporting were also considered. 


\section{RESULTS}

\section{Recommendations}

Based on the Google search results, nonspecific prevention recommendations at a national level were found in the following countries:

1) Australia ${ }^{13}$

2) Scotland-United Kingdom ${ }^{14}$

3) Ireland ${ }^{15}$

4) Singapore ${ }^{16}$

5) United States of America ${ }^{17}$

6) $\mathrm{Canada}^{18}$

The search through the web sites of pediatric societies found the Consensus of the Venezuelan Society of Child Care and Pediatrics (Sociedad Venezolana de Puericultura y Pediatría) on day care centers. ${ }^{19}$

The guidelines found have been published by health organizations or health and education interdisciplinary task forces. Five of these guidelines (from Australia, Scotland-United Kingdom, United States of America, Ireland, and Singapore) are aimed at day care staff, while the ones published by Canada and Venezuela are aimed at pediatricians.

Table 1 shows a comparison of recommendations by thematic focus.

All guidelines include a thorough explanation on hand hygiene. In all cases, it is recommended that staff wash their hands with liquid soap and running water and dry them using disposable paper towels, and to use alcohol gel hand sanitizer only if no water is available or after washing their hands with water. Only three of the seven analyzed guidelines specifically indicate to wash children's hands.

Breastfeeding promotion is mentioned only in the Venezuelan recommendations. Although the USA guidelines include an annex with links to breastfeeding promotion centers, this measure is not described as a prevention against infections.

The recommendations on respiratory hygiene are briefly mentioned in five of the analyzed guidelines. These recommend to clear secretions with disposable tissues, followed by hand washing.

All guidelines recommend to clean the environment and elements, but with different levels of detail and accuracy. This measure always involves wiping all surfaces, washing toys with water and detergent, and frequently airing all rooms.

The recommendations regarding exclusion of sick children and staff vary in terms of criteria and specificity. Most guidelines consider that respiratory symptoms per se, with no malaise, fever or an etiological diagnosis, do not account for an exclusion criterion.

\section{Evidence}

Figure 1 shows the results of the literature search for evidence. No articles were found in the reviewed congress publications that complied with the eligibility criteria.

Eventually, eight studies were selected according to the eligibility criteria..$^{20-27}$

No study analyzed the effect of a single measure. However, these articles corresponded to studies on the impact of training programs and the simultaneous implementation of several measures. No publication related to breastfeeding or the exclusion of symptomatic subjects was found. All studies resulting from the search referred to the following themes: hand hygiene, cleaning of the environment and common elements, and nasal hygiene. Five of the articles described different training approaches. ${ }^{20-24}$

The results are not consistent among the various studies (Table 2).

Only one study ${ }^{24}$ shows a low risk of bias. The rest have significant methodological limitations, either because the study used products manufactured by the study sponsor, ${ }^{24}$ there was no randomization, ${ }^{25,26}$ or randomization was not described, ${ }^{20}$ data collectors were not blinded to the intervention, ${ }^{26,27}$ inter-center variability was not considered in the study design ${ }^{23}$ or the study analysis, ${ }^{20,22}$ or compared groups were not similar. ${ }^{25,26}$ In addition, studies conducted at a single center show weak external validity ${ }^{21,27}$ (Table 2).

\section{DISCUSSION}

Given the entrance of mothers into the labor market, there is an increasing need to hire services to look after children outside the house. ${ }^{28}$ The prevention of respiratory infections in the setting of facilities which offer these services is a major challenge that requires a solution. Few countries have guidelines or recommendations aimed at day care center staff. Besides, there is limited evidence on the effectiveness of non-specific prevention measures at day care centers. Instead, specific prevention alternatives (immunizations and chemoprophylaxis) have been extensively studied..$^{29,30}$ There are also recommendations in this regard, such as the Consensus on prevention at day care centers developed by the Argentine Society of Pediatrics. ${ }^{31}$ Such consensus provides 
TABLE 1. Comparison of different country recommendations by thematic focus

\begin{tabular}{|c|c|c|c|c|c|c|}
\hline $\begin{array}{l}\text { Thematic } \\
\text { focus/ cour }\end{array}$ & $\begin{array}{l}\text { Published by } \\
\text { intry }\end{array}$ & $\begin{array}{c}\text { Hand } \\
\text { hygiene }\end{array}$ & Breastfeeding & $\begin{array}{l}\text { Secretion } \\
\text { hygiene }\end{array}$ & $\begin{array}{l}\text { Environment } \\
\text { hygiene }\end{array}$ & $\begin{array}{c}\text { Exclusion of subjects } \\
\text { with respiratory } \\
\text { symptoms }\end{array}$ \\
\hline Australia & $\begin{array}{l}\text { National Health } \\
\text { and Medical } \\
\text { Research Council }\end{array}$ & $\begin{array}{c}\text { Wash children's } \\
\text { hands. } \\
\text { Do not use } \\
\text { antibacterial soap. } \\
\text { Do not use hot } \\
\text { air hand dryer. } \\
\text { Avoid wearing } \\
\text { jewelry. }\end{array}$ & $\begin{array}{c}\text { Not } \\
\text { mentioned. }\end{array}$ & $\begin{array}{l}\text { No additional } \\
\text { details. }\end{array}$ & $\begin{array}{l}\text { It specifies } \\
\text { procedures and } \\
\text { frequency. }\end{array}$ & $\begin{array}{l}\text { Specified for cases and } \\
\text { contacts, both children } \\
\text { and adults. It is not } \\
\text { necessary to exclude } \\
\text { subjects with certain } \\
\text { infections (RSV). }\end{array}$ \\
\hline Scotland & $\begin{array}{l}\text { Health Protection } \\
\text { Agency }\end{array}$ & $\begin{array}{c}\text { Do not use } \\
\text { antibacterial } \\
\text { soap. Cloth } \\
\text { towels may be } \\
\text { used if washed } \\
\text { after each use. }\end{array}$ & $\begin{array}{l}\text { It mentions breast } \\
\text { milk in food control } \\
\text { procedures, but } \\
\text { not in relation } \\
\text { with infection } \\
\text { prevention. } \\
\end{array}$ & $\begin{array}{l}\text { No additional } \\
\text { details. }\end{array}$ & $\begin{array}{l}\text { It specifies a } \\
\text { procedure. } \\
\text { It does not } \\
\text { recommend the } \\
\text { frequency. }\end{array}$ & $\begin{array}{c}\text { It refers to specific } \\
\text { criteria. It does not } \\
\text { exclude children with } \\
\text { cough and secretions, } \\
\text { except they experience } \\
\text { malaise. }\end{array}$ \\
\hline Ireland & $\begin{array}{l}\text { Preschool and } \\
\text { Childcare } \\
\text { Facility } \\
\text { Subcommittee, } \\
\text { Surveillance } \\
\text { Center } \\
\end{array}$ & $\begin{array}{l}\text { Wash children's } \\
\text { hands. } \\
\text { Avoid wearing } \\
\text { jewelry. } \\
\text { Staff should have } \\
\text { trimmed nails. }\end{array}$ & $\begin{array}{c}\text { Not } \\
\text { mentioned. }\end{array}$ & $\begin{array}{l}\begin{array}{l}\text { No additional } \\
\text { details. }\end{array} \\
\text { It } \\
\text { er } \\
\end{array}$ & $\begin{array}{l}\text { It specifies a } \\
\text { procedure. } \\
\text { It recommends the } \\
\text { frequency. } \\
\text { It mentions } \\
\text { environment airing. }\end{array}$ & $\begin{array}{c}\text { Exclusion of } \\
\text { symptomatic children } \\
\text { and adults. }\end{array}$ \\
\hline Singapore & $\begin{array}{l}\text { Infection } \\
\text { Control } \\
\text { Association }\end{array}$ & $\begin{array}{c}\text { No additional } \\
\text { details. }\end{array}$ & $\begin{array}{c}\text { Not } \\
\text { mentioned. }\end{array}$ & $\begin{array}{l}\text { No additional } \\
\text { details. }\end{array}$ & $\begin{array}{l}\text { It specifies a } \\
\text { procedure. } \\
\text { It recommends } \\
\text { the frequency. }\end{array}$ & $\begin{array}{c}\text { Exclusion in specific } \\
\text { situations. } \\
\text { Detailed only for } \\
\text { TBC and influenza. }\end{array}$ \\
\hline $\begin{array}{l}\text { United } \\
\text { States of } \\
\text { America }\end{array}$ & $\begin{array}{c}\text { American Academy } \\
\text { of Pediatrics, } \\
\text { American Public } \\
\text { Health Association, } \\
\text { and National } \\
\text { Resource Center for } \\
\text { Health } \\
\text { and Safety in } \\
\text { Childcare and } \\
\text { Early Education }\end{array}$ & $\begin{array}{l}\text { Do not use } \\
\text { paper rolls. } \\
\text { Help children } \\
\text { wash their } \\
\text { hands. } \\
\text { Do not use } \\
\text { antibacterial } \\
\text { soap. } \\
\text { Place a } \\
\text { reminder sign. } \\
\text { Do not wear fake } \\
\text { nails or jewelry. }\end{array}$ & $\begin{array}{l}\text { It includes an } \\
\text { annex on breast- } \\
\text { feeding promo- } \\
\text { tion centers and } \\
\text { several links. } \\
\text { No } \\
\text { recommendation. } \\
\end{array}$ & $\begin{array}{l}\text { No additional } \\
\text { details. }\end{array}$ & $\begin{array}{l}\text { It specifies a } \\
\text { procedure. } \\
\text { It recommends } \\
\text { the frequency. } \\
\text { It mentions } \\
\text { environment } \\
\text { airing. It } \\
\text { prohibits } \\
\text { tobacco use. }\end{array}$ & $\begin{array}{l}\text { Exclusion of children } \\
\text { and adults with } \\
\text { alaise. }\end{array}$ \\
\hline Canada & $\begin{array}{l}\text { Canadian } \\
\text { Pediatric } \\
\text { Society }\end{array}$ & $\begin{array}{l}\text { Place a } \\
\text { reminder sign. }\end{array}$ & $\begin{array}{c}\text { Not } \\
\text { mentioned. }\end{array}$ & $\begin{array}{l}\text { Not mentioned } \\
\text { in national } \\
\text { guidelines. } \\
\text { (Detailed in local } \\
\text { guidelines.) } \\
\end{array}$ & $\begin{array}{c}\text { No additional } \\
\text { details. } \\
\text { (Detailed in local } \\
\text { guidelines.) }\end{array}$ & $\begin{array}{l}\text { Not specified. } \\
\text { (Detailed in local } \\
\text { guidelines.) }\end{array}$ \\
\hline Venezuela & $\begin{array}{c}\text { Venezuelan } \\
\text { Society of Child } \\
\text { Care and } \\
\text { Pediatrics }\end{array}$ & $\begin{array}{c}\text { Use a } \\
\text { nail brush. }\end{array}$ & $\begin{array}{l}\text { Day care center } \\
\text { should provide } \\
\text { a room for milk } \\
\text { expression and } \\
\text { a refrigerator } \\
\text { for storage. } \\
\text { Day care center } \\
\text { should feed } \\
\text { infants aged } 0 \text { to } \\
6 \text { months old } \\
\text { sing a bottle or cup }\end{array}$ & $\begin{array}{l}\text { Not mentioned } \\
\text { in national } \\
\text { guidelines. } \\
\text { (Detailed } \\
\text { in local } \\
\text { guidelines.) }\end{array}$ & $\begin{array}{l}\text { No additional } \\
\text { details. } \\
\text { It mentions } \\
\text { environment } \\
\text { airing. }\end{array}$ & $\begin{array}{l}\text { Exclusion of children } \\
\text { with fever and/or } \\
\text { malaise. }\end{array}$ \\
\hline
\end{tabular}

Hand hygiene: in all cases, this implies washing the hands with liquid soap and running water, and using alcohol gel sanitizer only if no water is available or after using water, using disposable paper towels, and an indication of the moment or situation when hand washing is required.

Clearance of secretions: this implies clearing secretions with disposable tissues, followed by hand washing.

Environment hygiene: this implies washing elements and surfaces with water and detergent.

ТВC: tuberculosis.

RSV: respiratory syncytial virus. 
FIGURE 1. Search and article selection process

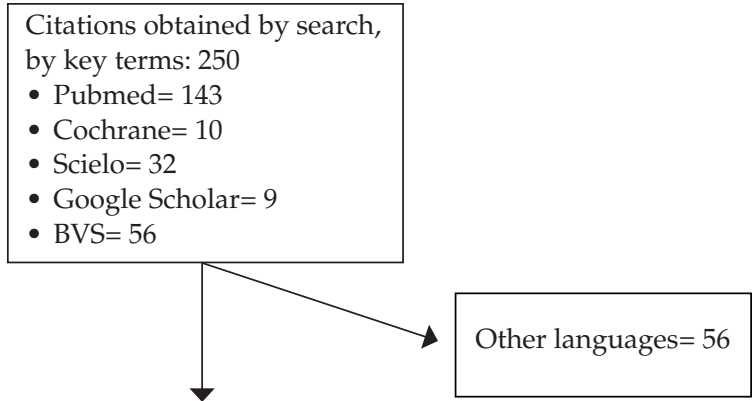

Citations in Spanish and

English $=194$

- Pubmed $=115$

- Cochrane= 10

- Scielo= 29

- Google Scholar= 8

- $\mathrm{BVS}=32$ valuable information, but it refers exclusively to specific prevention and is aimed at health care professionals.

Although there is disagreement on the level of detail provided by the recommendations, both hand washing with liquid soap and running water followed by drying with disposable tissues and frequent cleaning of toys, elements and the environment with water and detergent are universal measures outlined by all guidelines.

Not all guidelines are directly aimed at day care center staff, some are written for health care professionals who may act as advisors at these facilities. Such disparity in recipients, together with the fact that some countries (e.g., Canada) have regional guidelines which are more thorough than national guidelines, may account for the differences observed in the recommendations found.

Eight intervention studies on this topic were found. Caution should be exercised when interpreting these results because dependent outcome measures have inaccurate and varied definitions and because data were appraised in different manners, therefore hindering their comparison. These interventions also imply compliance on the part of various people, and since not all studies were able to follow-up on such compliance, ${ }^{25,-27}$ it is not possible to certainly infer if the impact, or lack of it, is the result of the study intervention. Measured results depend on multiple factors that require to be adjusted in order to attribute modifications in infection rates principally to the study intervention. It is not easy to assess this type of complex interventions. ${ }^{32}$ Even though there is no ideal design, cluster studies are the most commonly used.

Therefore, the influence of each cluster, which represents a center where the intervention takes place, on the measured result should be taken into consideration: the organizational structure or description of all day care centers are not homogenous, so the intervention scenario is not necessarily the same across all studies, or even within the same study.

In addition, the cluster design allows to estimate the impact of the intervention as implemented during the study and exclusively on the study population. The effects may not be the same in other situations or populations because the quality and intensity of the intervention is always larger in the context of a research study, because effects may change 
depending on the population characteristics, or because the implementation of the intervention may vary across different populations. The internal validity of the study is also affected by the asymmetry in subjects' baseline characteristics; however, financial and operational reasons make cluster studies have a relatively small number of clusters, resulting in a relatively frequent imbalance. ${ }^{33}$

Particularly, in the case of interventions aimed at infectious diseases, the variable incidence of each disease is a relevant confounding factor, which is

TABLE 2. Intervention studies on the effectiveness of non-specific prevention measures against respiratory infections at day care centers

\begin{tabular}{|c|c|c|c|c|}
\hline Reference & Population/centers & Methods & Results & $\begin{array}{l}\text { Risk of bias/ } \\
\text { methodological quality }\end{array}$ \\
\hline Kotch, 1994 & $\begin{array}{l}371 \text { children aged } \\
<36 \text { months old }\end{array}$ & $\begin{array}{l}\text { Continued training } \\
\text { on hand washing and } \\
\text { environment hygiene. } \\
\text { Topic promotion among } \\
\text { DCC directors. }\end{array}$ & $\begin{array}{l}\text { Intervention versus control: } \\
\text { respiratory events/year/child: } \\
13.98 \text { versus } 14.8 \mathrm{NS} \\
\text { Respiratory events with } \\
\text { fever/year/child: } \\
4.2 \text { versus } 4.99 \mathrm{NS}\end{array}$ & $\begin{array}{l}\text { Randomization is not described. } \\
\text { Baseline imbalance: the } \\
\text { characteristics of centers where } \\
\text { the intervention took place made } \\
\text { them more prone to infections. } \\
\text { Compliance was observed. } \\
\text { No denominators reported. }\end{array}$ \\
\hline Krilov, 1996 & $\begin{array}{l}38 \text { children aged } \\
45 \text { days old to } \\
5 \text { years old } \\
\text { Children } \\
\text { with Down's } \\
\text { syndrome } \\
1 \text { DCC (16 groups) } \\
\text { USA }\end{array}$ & $\begin{array}{c}\text { Design: before-after. } \\
\text { Training on hand } \\
\text { washing and } \\
\text { environment hygiene. } \\
\text { Environment hygiene } \\
\text { program (including the } \\
\text { school bus). Provision } \\
\text { of cleaning products. } \\
\text { Program monitoring. }\end{array}$ & $\begin{array}{l}\text { Respiratory infections / children } \\
\text { before and after: } \\
0.67 \text { versus } 0.42 p<0.07\end{array}$ & $\begin{array}{l}\text { Small sample size. The studied } \\
\text { sample is } 1 / 3 \text { of eligible } \\
\text { participants. } \\
\text { Uses the sponsor's products. } \\
\text { Single center. } \\
\text { Compliance monitoring. }\end{array}$ \\
\hline Carabin, 1999 & $\begin{array}{c}1729 \text { children aged } \\
18 \text { to } 36 \text { months old } \\
47 \text { DCC } \\
\text { (83 groups) } \\
\text { Canada }\end{array}$ & $\begin{array}{l}\text { Design: randomized } \\
\text { clusters. } \\
\text { Training on hand } \\
\text { washing and } \\
\text { environment hygiene. } \\
\text { Recommendations on } \\
\text { procedures and frequency. }\end{array}$ & $\begin{array}{c}\text { IRR of upper respiratory } \\
\text { infections }=0.8 \\
(95 \% \text { CI: } 0.68-0.93)\end{array}$ & $\begin{array}{l}\text { Loss of clusters and groups. } \\
\text { The analysis did not } \\
\text { consider the cluster. } \\
\text { The design is confusing. No } \\
\text { denominators presented. } \\
\text { Compliance monitoring was } \\
\text { conducted by phone. }\end{array}$ \\
\hline Uhari, 1999 & $\begin{array}{c}1522 \text { children; } \\
3.5 \pm 1.9 \text { years old } \\
20 \text { DCC } \\
\text { Finland }\end{array}$ & $\begin{array}{c}\text { Design: randomized, } \\
\text { controlled. } \\
\text { Periodic training on hand } \\
\text { washing and environment } \\
\text { hygiene. Training on } \\
\text { exclusion of symptomatic } \\
\text { subjects. Nurse visit } \\
\text { to every center } \\
\text { every two weeks. }\end{array}$ & $\begin{array}{c}\text { Intervention versus control: } \\
\text { infectious events in children } \\
<3 \text { years old: } 7.8 \\
\text { versus } 8.6 \mathrm{p}=0.002 \\
\text { Rhinitis: } 5.8 \text { versus } 6.6 \text { - } \\
\text { Cough: } 4.2 \text { versus } 4.8 \text {. } \\
\text { Less days with symptoms, } \\
\text { higher level of absenteeism } \\
\text { and more doctor visits } \\
\text { among the staff. } \\
\text { Compliance variable: } 60 \text { to } 90 \%\end{array}$ & $\begin{array}{l}\text { The design does not consider } \\
\text { inter-center variability. } \\
\text { Compliance monitoring. }\end{array}$ \\
\hline Roberts, 2000 & $\begin{array}{l}558 \text { children aged } \\
<3 \text { years old }\end{array}$ & $\begin{array}{l}\text { Design: clusters, } \\
\text { randomized } \\
\text { Periodic training } \\
\text { on hand washing. }\end{array}$ & $\begin{array}{l}\text { RR of upper respiratory } \\
\text { infections with intervention: } \\
0.95(0.89-1.01) \mathrm{p}=0.10 . \\
\text { RR of upper respiratory } \\
\text { infections }<24 \text { m.o. } \\
\text { with intervention: }\end{array}$ & $\begin{array}{c}\text { Cluster have similar } \\
\text { baseline characteristics. } \\
\text { The inter-cluster coefficient and } \\
\text { analysis are presented by } \\
\text { randomization unit. }\end{array}$ \\
\hline & Australia & $\begin{array}{l}\text { Use of plastic bags } \\
\text { besides tissues, } \\
\text { followed by } \\
\text { hand washing. }\end{array}$ & $\begin{array}{c}0.9(0.83-0.97) \mathrm{p}=0.01 \text {. } \\
\text { With high compliance } \\
\text { of hand washing and nasal } \\
\text { hygiene; colds reduced } 17 \% \text {. }\end{array}$ & $\begin{array}{l}\text { Compliance monitoring, } \\
\text { but no results presented. }\end{array}$ \\
\hline
\end{tabular}




\begin{tabular}{|c|c|c|}
\hline \multirow[t]{2}{*}{ Ponka, 2004} & $\begin{array}{l}3051 \text { children aged } \\
>1-<3 \text { years old }\end{array}$ & $\begin{array}{l}\text { Design: non } \\
\text { randomized clusters. } \\
\text { Single training on } \\
\text { hand washing and } \\
\text { environment hygiene. }\end{array}$ \\
\hline & $\begin{array}{c}14337 \text { children } \\
\text { aged } \geq 3 \text { years old } \\
288 \text { DCC } \\
\text { (17 } 388 \text { children) } \\
\text { Finland }\end{array}$ & $\begin{array}{c}\text { Exclusion of } \\
\text { symptomatic children. } \\
\text { Written instructions } \\
\text { for parents. } \\
\text { Provision of hygiene } \\
\text { materials. }\end{array}$ \\
\hline Hedin, 2006. & $\begin{array}{l}311 \text { children aged } \\
1-5 \text { years old } \\
63 \text { adults } \\
6 \text { DCC } \\
\text { Sweden }\end{array}$ & $\begin{array}{l}\text { Controlled, } \\
\text { intervention study. } \\
\text { Staff was warned on } \\
\text { official recommendations } \\
\text { Promotion of outdoor } \\
\text { activities with children. } \\
\text { Informative posters } \\
\text { placed at entrances. } \\
\text { The topic was discussed } \\
\text { at parent meetings. } \\
\text { Provision of liquid soap } \\
\text { and paper towels. }\end{array}$ \\
\hline
\end{tabular}

Intervention versus control:

Difference in the reduction of absenteeism due

to respiratory infections.

Upper/month in 1000 children aged $<3$ years old: $-101(-189-13) \mathrm{p}=0.025$
No description of children's baseline characteristics. No description of center selection.

The age structure of children at centers where the intervention took place was different from those at the control centers.

No randomization.

No compliance monitoring.

\author{
Intervention versus control \\ Percentage of absenteeism \\ due to sickness compared to \\ expected percentage: \\ 6.6 vs. $6.8 \mathrm{NS}$ \\ Percentage of absenteeism \\ due to respiratory infection: \\ 55.9 versus $61.6 \mathrm{NS}$ \\ No randomization. \\ No clear description \\ of center selection. \\ DCC were not "similar" \\ because control DCC staff \\ knew "more" about \\ respiratory infections. \\ Differences observed in the \\ number of siblings and \\ family members with asthma. \\ The analysis does not consider \\ the cluster, it deals with \\ two separate groups. \\ Reporting bias on the \\ part of teachers. \\ No compliance monitoring. \\ Improved hygiene could \\ be the result of being \\ under observation. \\ Weak external validity. \\ Gel is not always available.
}

\begin{tabular}{|c|c|c|c|}
\hline Correa, 2012 & $\begin{array}{l}1727 \text { children } \\
\text { aged } \\
1-5 \text { years old } \\
42 \text { DCC } \\
\text { Restricted access } \\
\text { to water. } \\
\text { Colombia }\end{array}$ & $\begin{array}{c}\text { Design: clusters, } \\
\text { randomized } \\
\text { Training on } \\
\text { hand hygiene. } \\
\text { s Provision of alcohol gel, } \\
\text { with availability monitoring. }\end{array}$ & $\begin{array}{l}\text { Respiratory infection/ } \\
\text { year/child: } \\
\text { 2.06 versus } 2.18 \mathrm{NS} \\
\text { Upon adjustment, differences } \\
\text { were observed in } 2^{\text {nd }} \text { and } 3^{\text {rd }} \\
\text { quarter of intervention } \\
\text { (HR: } 0.8 \text { and } 0.63 \text { ). }\end{array}$ \\
\hline
\end{tabular}

DCC: day care center.

NS: not significant.

IRR: incidence rate ratio.

HR: hazard ratio.

usually avoided in either cluster or before-after study designs.

Taken together, it cannot be inferred that the studied intervention programs will have an effect, once implemented, on the reduction of respiratory infection dissemination. Notwithstanding, some of the studies also analyzed the effect on gastrointestinal infections and showed a certain degree of reduction in their incidence. ${ }^{20-22,25}$ The transmission modes of gastrointestinal infections and, therefore, their prevention, are usually the same as in respiratory infections. Moreover, an adequate hand hygiene has proven to be effective in gated community studies, a setting that differs from day care centers. ${ }^{7}$
This suggests that the assessed measures could have a beneficial effect which may have been inadequately measured or whose extent is not large enough as to be detected in the analyzed sample sizes.

The available evidence supports the effect of breastfeeding; ${ }^{8}$ however, it has not been confirmed by intervention studies at day care centers. The data collected in an observational study conducted at a day care center in the province of Buenos Aires from 2004 to 2007 show a $9.4 \%$ rate of absenteeism due to sickness among infants exclusively breastfed up to six months old versus $21.5 \%$ among infants fed with other types of milk. Although results were not adjusted 
considering other outcome measures, and this is a study limitation, such difference was observed in all yearly periods and across all ages. ${ }^{34}$

Isolation or separation of symptomatic subjects as a measure to reduce the dissemination of respiratory infections have been studied at hospitals and military headquarters, but results were heterogeneous. ${ }^{9}$

The scarce number of studies in our area of concern makes it impossible to establish the impact of such measures under these circumstances. Given the methodological difficulties observed when assessing the results of this type of interventions, we could apply Nebot's principle of prevention. Positive effects could be expected from certain interventions, although it is no possible to verify them completely. It is more reasonable to implement certain measures than to have no intervention because its effects cannot be assessed..$^{35}$

Respiratory infections at day care centers have become an increasingly significant problem. It is therefore necessary to know the current situation in our setting, develop future studies to assess the feasibility of implementing different prevention strategies and their effectiveness in order to publish recommendations based on the best available evidence.

\section{CONCLUSION}

A timely and adequate hand hygiene and appropriately cleaning the environment have been uniformly recommended by different guidelines as non-specific prevention measures against respiratory infections. The evidence on the usefulness of these measures in this setting is limited, and the nature of this subject makes it difficult to study, but given the growing relevance of this problem, it is essential to find new evidence to face it.

\section{Acknowledgments}

To Norma Rossato, M.D., Mariana Ceriotto, M.D., and Néstor Vain, M.D., for taking the time to read the manuscript and making valuable suggestions.

\section{REFERENCES}

1. Nair H, Simoes EA, Rudan I, Gessner BD, et al. Global and regional burden of hospital admissions for severe acute lower respiratory infections in young children in 2010: a systematic analysis. Lancet 2013;381(9875):1380-90.

2. Ministerio de Salud. Presidencia de la Nación Argentina. Defunciones de menores de cinco años. Indicadores seleccionados. Argentina 2010. Boletín 135. Ciudad Autónoma de Buenos Aires, 2010. [Accessed on: August 12, 2013]. Avail- able at:http:/ / www.deis.gov.ar/ publicaciones/Archivos/ Boletin135.pdf.

3. McCutcheon H, Fitzgerald M. The public health problem of acute respiratory illness in childcare. J Clin Nurs 2001;10(3):305-10.

4. Carabin H, Gyorkos TW, Soto JC, Penrod J, et al. Estimation of direct and indirect costs because of common infections in toddlers attending day care centers. Pediatrics 1999;103(3):556-64.

5. Kamper-Jorgensen M, Wohlfahrt J, Simonsen J, Gronbaek M, Benn CS. Population-based study of the impact of childcare attendance on hospitalizations for acute respiratory infections. Pediatrics 2006;118(4):1439-46.

6. Da Dalt S, Bressan S, Martinolli F, Perilongo G, Baraldi E. Treatment of bronchiolitis: state of the art. Early $\mathrm{Hu}$ man Dev 2013:89(Suppl 1)S31-6.

7. Aiello AE, Coulborn RM, Perez V, Larson EL. Effect of hand hygiene on infectious disease risk in the community setting: a meta-analysis. Am J Public Health 2008;98(8):1372-81.

8. Duijts L, Ramadhani MK, Moll HA. Breastfeeding protects against infectious diseases during infancy in industrialized countries. A systematic review. Matern Child Nutr 2009; 5(3):199-210.

9. Jefferson T, Del Mar C, Dooley L, Ferroni E, et al. Physical interventions to interrupt or reduce the spread of respiratory viruses: systematic review. BMJ 2009;339(b3675).

10. SAP. Material de Congresos realizados entre 2005 y 2012. [Accessed on:August 12, 2013]. Available at: http:/ / www3. sap.org.ar/congresos/index.php?option $=\mathrm{com}_{-}$ content\&v iew $=$ article\&id $=69 \&$ Itemid $=78$.

11. PAS/ASPR. Pediatric Academic Societies and Asian Society for Pediatric Research. Joint Meeting. Denver, 2011. [Accessed on: August 12, 2013]. Available at: http:/ / www. pas-meeting. org/past/2011Denver/default.asp.

12. PAS. Pediatric Academic Societies Annual Meeting April 28May I. Boston, 2012. [Accessed on: August 12, 2013]. Available at: http:/ / www.pas-meeting.org/ past/2012Boston/ default.asp.

13. Australian Government. National Health and Medical Research Council. Staying Healthy in Child Care. Preventing infectious disease in child care. 4th edition. 2005. [Accessed on: August 12, 2013]. [Available at: http:/ /www. nhmrc. gov.au/_files_nhmrc/publications/attachments/ ch43. pdf].

14. NHS Health Protection Scotland. Infection Prevention and Con- trolinChildCareSettings(Day Careand Childminding Settings). Glasgow, 2011. [Accessed on: August 12, 2013]. [Available at:http:/ /www.documents.hps.scot.nhs.uk/ hai/ infection-control/ guidelines/infection-prevention-controlchildcare.pdf.

15. HSE/HealthProtectionSurveillanceCentre. Management of Infectious Disease in Childcare Facilities and OtherChildcare Settings. Health Protection Surveillance Centre. [Accessed on: August 12, 2013]. Available at: http://www. hpsc.ie/ hpsc/A-Z/ LifeStages/Childcare/File,13444,en. pdf.

16. Ministry of Health Singapore. Infection Control Guidelines for Schools and Child Care Centres. 2nd Ed. Singapur, 2012. [Ac- cessed on: August 12, 2013]. Available at: http:// www.icas.org. sg/guidelines/IC\%20guidelines\%20for\%20 schools\%202nd\%20 Edition\%20June\%202012.pdf.

17. American Academy Pediatrics/American Public Health Associa- tion/National Resource Center for Health and Safety in Child Care and Early Education. Caring for Our Children: National Health and Safety Performance Stan-dards; Guidelines for Early Care and Education Programs. 3rd Ed. Elk Grove Village, IL: American Academy of Pe-diatrics; Washington, DC: American Public Health Asso-ciation. 2011. [Accessed on: August 12, 2013]. Available at: http:/ / www. 
healthybeveragesinchildcare.org/resou-rces/Caring ForOurChildren_NationalHealthandSafetyS-tandards.2011.pdf.

18. Health implications of children in child care centres. Part B: Inju- ries and infections. Paediatr Child Health 2009;14(1):40-8.

19. Primer Consenso de la SVPP sobre Guarderías. SVPP/A 2008;71(2):31-35.

20. Kotch JB, Weigle KA, Weber DJ, Clifford RM, et al. Evalu- ation of an Hygienic Intervention in Child Day-Care Centers. Pediatrics 1994;94(6 Pt 2);991-4.

21. Krilov LR, Barone SR, Mandel FS, Cusack TM, et al. Impact of an infection control program in a specialized preschool. Am J Infect Control 1996;24(3):167-73.

22. Carabin H, Gyorkos TW, Soto JC, Joseph L, et al. Effectiveness of a training program in reducing infections in toddlers attend- ing day care centers. Epidemiology 1999;10(3):219-27.

23. Uhari M, Möttönen M. An open randomized controlled trial of infection prevention in child day-care centers. Pediatr Infect Dis J 1999;18(8):672-7.

24. Roberts L, Smith W, Jorm L, Patel M, et al. Effect of infection control measures on the frequency of upper respiratory infec- tion in child care: a randomized, controlled trial. Pediatrics 2000;105(4 Pt 1):738-42.

25. Pönkä A, Poussa T, Laosmaa M. The effect of enhanced hygiene practices on absences due to infectious diseases among children in day care centers in Helsinki. Infection 2004;32(1):2-7.

26. Hedin K, Petersson C, Cars H, Beckman A, Hakansson A. Infection prevention at day-care centres: feasibility and possible effects of intervention. Scand J Prim Health Care 2006;24(1):44-9.

27. Correa JC, Pinto D, Salas LA, Camacho JC, et al. A cluster- randomized controlled trial of handrubs for prevention of infec- tious diseases among children in Colombia. Rev Panam Salud Publica 2012;31(6):476-84.
28. Repetto F, Diaz Langou G,Aulicino C. Cuidado infantilen la Ciudad Autónoma de Buenos Aires: ¿la disyuntiva entre pa-ñales y pedagogía? Agosto 2012. [Accessed on: January 23, 2014]. Available at: http://www.cippec.org/ docu ments $/ 10179 / 51827 / 93+\mathrm{DT}+$ Cuidado+infantil+en+la+ Ciudad+Aut $\%$ C3\%B3noma+de+Buenos+Aires $\% 2 \mathrm{C} \% 20$ Repetto \%2C\%20 Diaz+Langou+y+Aulicino\%2C\%20 2012. pdf/7ab9dc20-490f-4887-a303-5af66ede767d.

29. Jefferson T, RivettiA, Di Pietrantonj C, Demicheli V, Ferroni E. Vaccines for preventing influenza in healthy children. Cochrane Database Syst Rev 2012;15;8(CD004879).

30. Weil-Olivier C, van der Linden M, de Schutter I, Dagan $R$, Mantovani L. Prevention of pneumococcal diseases in the post-seven valent vaccine era: a European perspective. BMC Infect Dis 2012;12:207.

31. Sociedad Argentina de Pediatría. Consenso sobre Prevención de Infecciones en Jardines Maternales y Escuelas. Ciudad Autónoma de Buenos Aires, 1997. [Accessed on: August 14, 2013]. Available at: http://www.sap.org.ar/ consenso_sobre_prevencion_de_infe maternales_y_escuelas.php.

32. Morales Asencio JM, Gonzalo Jiménez E, Martín Santos FJ, Morilla Herrera JC. Salud Pública Basada en la Evidencia: re- cursos sobre la efectividad de intervenciones en la comunidad. Rev Esp Salud Pública 2008;82(1):5-20.

33. Hayes RJ, Moulton LH. Cluster Randomised Trials. Boca Raton: Chapman \& Hall/CRC Press; 2009. Págs.285-300.

34. Bonet Coll MA. Al Jardín Maternal, con leche materna... siempre es mejor. VI Congreso Fedalma "Lactancia materna, más que un alimento". Palmas de Mallorca. 26 y 27 de junio, 2009.

35. Nebot M. Health promotion evaluation and the principle of pre- vention. J Epidemiol Community Health 2006;60(1):5-6. 